\title{
South Africa's rising logistics costs: An uncertain future
}

\author{
Authors: \\ Jan H. Havenga ${ }^{1}$ \\ Zane P. Simpson ${ }^{1}$ \\ Anneke de Bod ${ }^{1}$ \\ Nadia M. Viljoen² \\ Affiliations: \\ ${ }^{1}$ Department of Logistics, \\ Stellenbosch University, \\ South Africa \\ ${ }^{2}$ Department of Industrial \\ and Systems Engineering, \\ University of Pretoria, \\ South Africa \\ Correspondence to: \\ Jan Havenga \\ Email: \\ janh@sun.ac.za \\ Postal address: \\ Private Bag X1, Matieland \\ 7602 , South Africa \\ Dates: \\ Received: 11 Aug. 2014 \\ Accepted: 22 Sept. 2014 \\ Published: 10 Dec. 2014 \\ How to cite this article: \\ Havenga, J.H., Simpson, \\ Z.P., De Bod, A. \& Viljoen, \\ N.M., 2014, 'South Africa's \\ rising logistics costs: An \\ uncertain future', Journal of \\ Transport and Supply Chain \\ Management 8(1), Art. \#155, \\ 7 pages. http://dx.doi. \\ org/10.4102/jtscm.v8i1.155

\section{Copyright:} \\ (C) 2014. The Authors. \\ Licensee: AOSIS \\ OpenJournals. This \\ work is licensed under \\ the Creative Commons \\ Attribution License.
}

Read online:
A country's competitiveness can be severely hampered by an uncompetitive freight logistics system. During the first decade of the 21st century, two in-depth models were developed for South Africa which provide a framework for measuring and improving the country's freight logistics system - the cost of logistics survey and the freight demand model. These models also allow for the development of scenarios for key identified risks. The objectives of this study were to provide an overview of South Africa's surface freight transport industry, identify key risks to national competitiveness and suggest ways in which these risks could be mitigated. Freight flows were modelled by disaggregating the national input-output model into 372 origin-destination pairs and 71 commodity groups, followed by distancedecay gravity-modelling. Logistics costs were calculated by relating commodity-level freight flows to the costs of fulfilling associated logistical functions. South Africa's economy is highly transport intensive. Excessive dependence on road freight transport exacerbates this situation. Furthermore, the road freight transport's key cost driver is fuel, driven in turn by the oil price. Scenario analysis indicated the risk posed by this rising and volatile input and should provide impetus for policy instruments to reduce transport intensity. As such, this study concluded that a reduction in freight transport intensity is required to reduce exposure to volatile international oil prices.

\section{Introduction}

\section{Background}

There is an intrinsic link between the logistics performance of a country and its productivity, competitiveness and sustainable economic growth (Arvis et al. 2008; Lakshmanan \& Anderson 2002; Limão \& Venables 2001; Rasamit 2003; Ravn \& Mazzenga 2004; Rodrigues, Bowersox \& Calantone 2005). In all these studies, a reduction of overall logistics costs bodes well for the respective economies. In addition, a significant portion of a country's infrastructure comprises logistics infrastructure. Ittmann (2012) summarises retrospective studies by Calderón and Servén (2010), Kessides (1993), Loayza and Odawara (2010) and the World Bank (2013), building a convincing case that infrastructure expansion is imperative to long-term economic growth, especially in developing countries. A detailed historical analysis spanning 106 years by Fedderke, Perkins and Luiz (2006) confirms this link between infrastructure investment and economic growth in South Africa.

The macroeconomic importance of understanding and measuring logistics costs is therefore evident, yet aggregate national measurements are rare. Worldwide, only five national logistics costs surveys have been completed every year over a 5-year period, with only two (South Africa and the USA) providing a time series of national logistics costs per cost component (Rantasila \& Ojala 2012). The value of these time series is evident in that both South Africa and the USA's logistics cost time series are primary references for the public and private sectors, annually stimulating inter alia debate, policy formulation and investment within the respective logistics landscapes (Viljoen 2013). It has also enabled the identification of the impact of a key exogenous cost driver - the oil price. The 2007 recent record US logistics costs as a percentage of gross domestic product (GDP) (9.9\%), was caused by soaring oil prices and tight road transport capacities (Gilmore 2013). In 2012, a third of South Africa's freight transport costs were attributable to fuel costs, estimated to increase to $40.0 \%$ in 2014 as a result of fuel price inflation (Havenga \& Simpson 2013).

South Africa ranks 50th out of 75 countries in the International Chamber Commerce (ICC) Open Markets Index 2013, 12th out of the G20 countries and ranks higher than all of its BRICS partners (Finger 2013), rendering the economy more exposed to international economic, financial and commodity market trends than many of its peers and trading partners. Sixty-four percent of South Africa's demand for liquid fuels is met through crude oil imports. In 2012, over 40\% (56 million barrels) of South Africa's crude oil needs were met by African imports, mainly from 
Nigeria and Angola, up from 15\% in 2010, with the balance being met from the Middle East. Both regions, however, are marred by geopolitical instability and this dependence on imported oil from high-risk regions for a crucial economic activity (freight transport) makes the South African economy very vulnerable (South African Foreign Policy Initiative 2013; Wabiri \& Amusa 2011).

\section{Objectives}

The objective of the research is the continuous measurement of both South Africa's internal and external logistics costs and the identification of the underlying drivers of these costs. These measurements must inform policy, infrastructure investment and operational improvements to reduce costs, for businesses, industry and society.

This article shares the findings of high-level results of South Africa's latest national logistics costs survey (Council for Scientific and Industrial Research [CSIR] 2014), details the impact of the oil price as the most prominent exogenous cost driver given South Africa's current transport intensive economic structure and suggests a way forward.

\section{Literature review}

Havenga, Simpson and De Bod (2012) and Havenga and Simpson (2014) provide a comprehensive narrative of how the rise of the globalised economy favoured increasing economic specialisation over the past two to three decades, consequently increasing global logistics demand. Statistics from the US logistics cost measurement (Wilson 2011) illustrate very clearly the trade-off made between inventory costs and transport costs over this period (Figure 1). By favouring strategies that reduce inventory levels (such as lean manufacturing or just-in-time inventory management), the demand for transport increased. These strategies were viable because the balance between the prime interest rate and the price of oil (the key exogenous cost drivers of inventory carrying cost and transport cost respectively) rendered it the least cost alternative for the overall logistics function. However, the increasing volatility and exponential rise in oil prices this century (Figure 2), may result in a turnaround in this trade-off in the coming years.

Through fuel price scenario analysis, Macharis et al. (2010) show that catchment areas increase in favour of intermodal transport terminals (i.e. barge-road and intermodal rail-road) in higher oil price scenarios. The degree of modal shift depends on the severity of oil price increases. The modal shift is further engineered through the appropriate internalisation of all externality costs per transport mode. Fields and Renne (2013) address the trade-offs between a sustainable future and oil consumption specifically and argue for a complete rethink of transport in the USA. They argue for an 'ethical transportation system' that does not injure or kill and that does not pollute. Furthermore, fuel should not be wasted and the system should not be expensive. They further outline the USA's ambitious

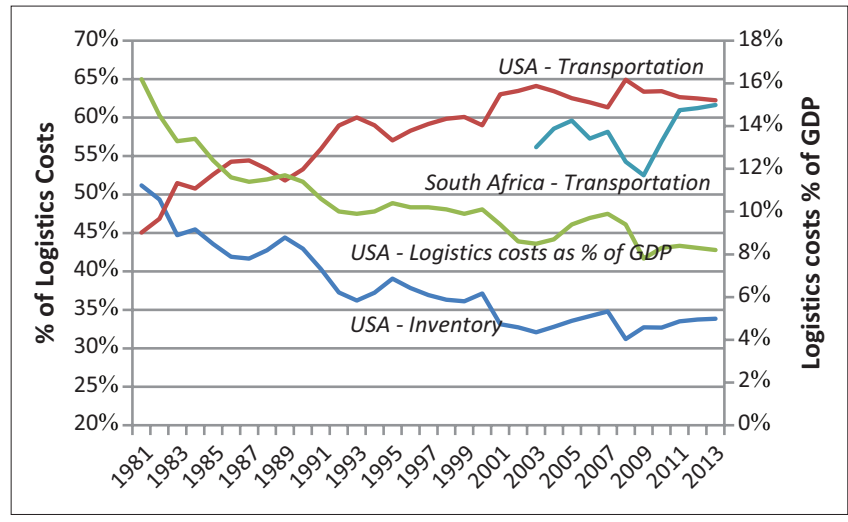

Source: Wilson, R., 2011, 21st annual State of Logistics report: The great freight recession, Council of Supply Chain Management Professionals, Washington, DC.

GDP, gross domestic product

FIGURE 1: The trade-off between inventory and transportation costs in the United States.

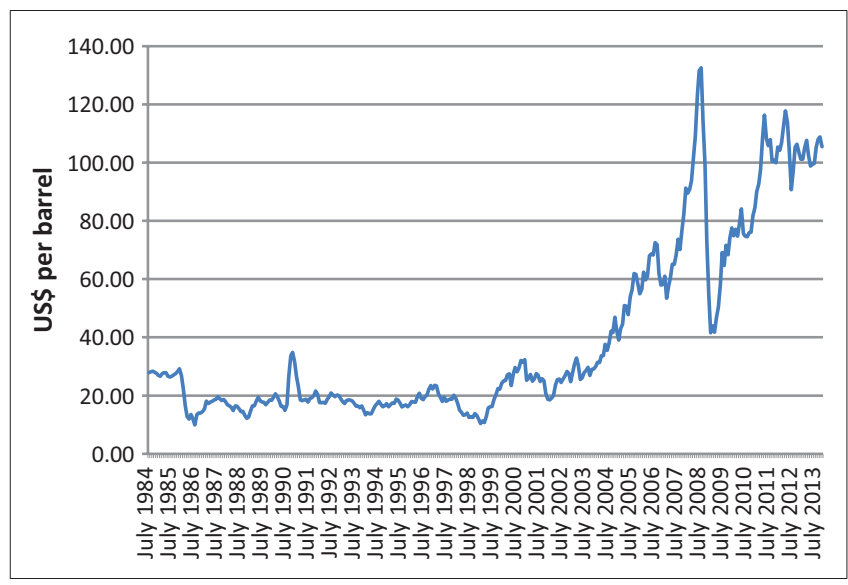

Source: IndexMundi, 2014, Dated Brent Monthly Price, West Texas Intermediate Monthly Price, Dubai Fateh Monthly Price, viewed 21 November 2014, from http://www.indexmundi. $\mathrm{com} /$ commodities/?commodity=crude-oil-brent\&months $=360$, http://www.indexmundi $\mathrm{com} /$ commodities/?commodity=crude-oil-west-texas-intermediate\&months $=360$ FIGURE 2: Monthly crude oil price -30 year trend.

plans to use rail and multimodality as the 'fundamental' element to achieve this.

Tavasszy et al. (2014:2) talk about the 'growing awareness of the need to curb the rapid increase of external costs of supply chains' and present the results of a study into the sectoral and regional effects of a full internalisation of all (quantifiable) external effects of supply chains worldwide. They find that the internalisation of external costs will only have a slight negative impact on economic growth and that this effect is offset by a decrease in emissions from using less fossil fuel. They conclude that where these effects are weighed against each other, a positive welfare impact appears. Major efforts in the world to address both growing supply chain costs and negative externalities (driven predominantly by rising fuel prices and a deep dependence on fossil fuels) can only be addressed by efficient and sustainable measurement systems.

\section{Research method and design}

Rantasila and Ojala (2012) provide an inventory of attempts to measure logistics costs on a national level around the world. They lament the fact that logistics costs are not included in 
any global ranking scales and that only five national surveys were completed consistently every year over the 5 years leading up to their study. As far as can be ascertained, South Africa's logistics costs survey, in its tenth consecutive year of publication (i.e. 2014), is the second longest-running global survey, following that of the USA, allowing for time series analyses of national logistics costs trends in both countries. They also confirm that information on national-level logistics performance and costs are becoming increasingly important in national and regional policymaking and competitiveness and that countries with a time series of data have a distinct advantage in this regard. They distinguish between statisticsbased measurements (such as South Africa's) and surveybased measurements (such as those for Finland).

\section{Logistics costs and freight flows}

Logistics costs can be broken down into three direct elements, namely transport, storage and handling costs. Additionally, there are management and administration costs and one indirect element, namely inventory carrying costs (i.e. timebased working capital financing the cost of inventory in the logistics chain). South Africa's logistics cost model employs a bottom-up approach for the computation of logistics costs by modelling total surface freight flow data for 83 commodity groups between 372 geographical areas - translating the tonnes produced and imported (i.e. total supply) of a specific commodity into total freight flows based on gravitymodelling and, subsequently, determining the costs of performing transport, storage and port handling functions with respect to that commodity. Actual disaggregated rail freight flows and costs were obtained from South Africa's single freight rail operator; the balance of the flow and cost data therefore defined the road transport mode.

The cost of holding inventory was added by calculating the average turn of each commodity in the economy, researching warehousing cost (storing and handling) and applying the prime rate to the average inventory delay.

Finally, management and administration costs were calculated by relating the relationship between the salary bill as a percentage of the costs of the transport industry for reward with the total costs of transport and warehousing to determine salary costs. The remainder of this component was calculated as the average profit margin in the transport industry for reward and other outsourced logistics activities, or, alternatively, as the administration charge for in-house transport or warehousing activities. The modelling approach is detailed in Havenga (2010).

From the first edition to the eighth edition of the State of Logistics $^{\mathrm{TM}}$ survey for South Africa, logistics costs were reported with a two-calendar-year lag, the reason being the time lag in publishing the previous year's economic data and the significant time required to collect and process the relevant economic and freight flow data that form the basis of the model. In the nineth State of Logistics ${ }^{\mathrm{TM}}$ survey, published in June 2013, the methodology was adapted to provide an estimate of the previous calendar year's (2012) costs. This was achieved by estimating 2012 freight flows based on the known data of two calendar years ago (2011) and then applying the actual cost drivers for 2012 (CSIR 2014). This estimation proved satisfyingly accurate for a first attempt - only missing the mark on total cost of logistics by $3 \%$. In the tenth State of Logistics ${ }^{\mathrm{TM}}$ survey (CSIR 2014), this was taken one step further - forecasting the cost of logistics for the current year, subject to fuel inflation, using the projected freight flow volumes and cost drivers. Fuel is the most volatile of all cost drivers and has a significant impact on total logistics costs; hence, in the forecast, fuel inflation is modelled separately (CSIR 2014).

\section{Oil price and exchange rate scenarios}

In the 1990s, the annual world oil price fluctuated between $\$ 13$ and \$23 per barrel (World Bank 2012). In 2000, leading economists from both public institutions (such as the World Bank and the US Department of Energy) and private companies (such as Deutsche Bank and Standard \& Poor's) forecast a 2010 oil price of between $\$ 14$ and \$21 (Radetzki 2002). What materialised, however, was an annual world oil price trading at between $\$ 24$ and $\$ 104$ per barrel since 2000, with an average oil price of $\$ 79$ per barrel for 2010 (World Bank 2012) - a margin of error of almost $400 \%$ compared to the 2010 forecasts made in 2000.

It is because of this volatility that it is crucial to measure the impact of the oil price on logistics costs and identify mitigation actions. In order to demonstrate the impact on logistics costs, three oil prices scenarios were defined. The optimistic \$100-per-barrel scenario was based on the average annual oil price of $\$ 104$ between 2011 and 2013 and for the 6 months leading up to June 2014. The bad \$150-per-barrel scenario was based on the historical high of $\$ 147$ per barrel of Brent crude reached in mid-July 2008 (Hopkins 2008). The worst-case \$300-per-barrel scenario combines the dynamism between physical production limits resulting from geological constraints and technological solutions (and therefore increased production) enabled by higher oil prices (Benes et al. 2012). Further deterioration of the oil price is also supported by an increase in money supply by the US Federal Reserve Bank, resulting in depreciation of the Dollar, uncertainty about future oil supplies in a peak-production world compounded by increased demand from countries such as China and India and political turmoil in the Middle East, the world's largest oil supply region (Peak Oil 2012; Thicknesse 2012).

The South African Rand/US Dollar exchange rate scenarios were defined as follows. The optimistic scenario of R8.00/ \$1.00 was based on the average annual exchange rate of R8.17/ \$1.00 between 2009 and 2013, whilst the bad scenario of R10.00/ $\$ 1.00$ was based on the annual peak this century of R10.52/\$1.00 in 2002 (South African Reserve Bank 2012). The worst-case scenario of R12.00/ \$1.00 was informed by the high of R13.84/ \$1.00 reached in December 2001 (moderated by the 2002 peak) (Grandes, Peter \& Pinaud 2003) and was driven by emergency market jitters and nationalism in an environment of political turmoil and severe crude oil shortages. 


\section{Results}

\section{South Africa's national logistics costs}

Figure 3 shows the national logistics costs broken down into components from 2006 (earlier years available in Havenga \& Simpson 2013) and the cost of logistics as a percentage of GDP. The largest cost component of total logistics costs throughout the past decade has always been transport costs. In 2012, transport costs accounted for $61.2 \%$ of logistics costs, whilst in 2013 this percentage was estimated at $61.6 \%$ (CSIR 2014). Given the high level of uncertainty in the South African logistics sector caused by the rapidly rising price of fuel, the 2014 iteration of the logistics cost calculation included a minimum and maximum forecast of logistics costs for 2014, depending on fuel inflation. The minimum forecast assumed that the average price of diesel in 2014 would be equal to the average in 2013, resulting in total logistics costs of R456 billion. The maximum assumed the 2014 average to be $15.0 \%$ higher than in 2013 , resulting in logistics costs of R470 billion. This was a highly conservative maximum, given that by mid-April 2014 (at the time of calculation) the increase in the diesel price was already $11.3 \%$.

Logistics costs as a percentage of the national GDP plateaued at $12.5 \%$ between 2011 and 2013, with an increase expected in 2014 depending on the final outcome of fuel inflation. However, logistics costs as a percentage of the transportable GDP (i.e. GDP earned only in the primary and secondary sectors of the economy) has steadily increased since 2010, standing at an estimated $46.7 \%$ of transportable GDP in 2013. It is therefore costing South Africa more, year-on-year, to move products along the supply chain (Figure 4). A key macroeconomic policy question is whether this is a result of deteriorating logistics efficiencies or increasing exogenous costs.

Comparing the individual components of logistics costs to the Consumer Price Index (CPI), growth in 'management and administration' and 'transportation costs' have recently outpaced growth in the CPI (Figure 5). The rising oil price (Figure 2) was regarded as the primary cause of the growth in transport costs, whilst record low interest rates and increased efficiencies in inventory management practices were credited for the slower growth in warehousing and inventory carrying costs. The trend in the growth of managementand administration costs was attributed to more employees (excluding drivers) in the transport sector and a growth in the wages of these individuals that is above the inflation rates (CSIR 2014).

When 2009 was taken as the index year, costs related to fuel inflation alone became significant (Figure 6). Under

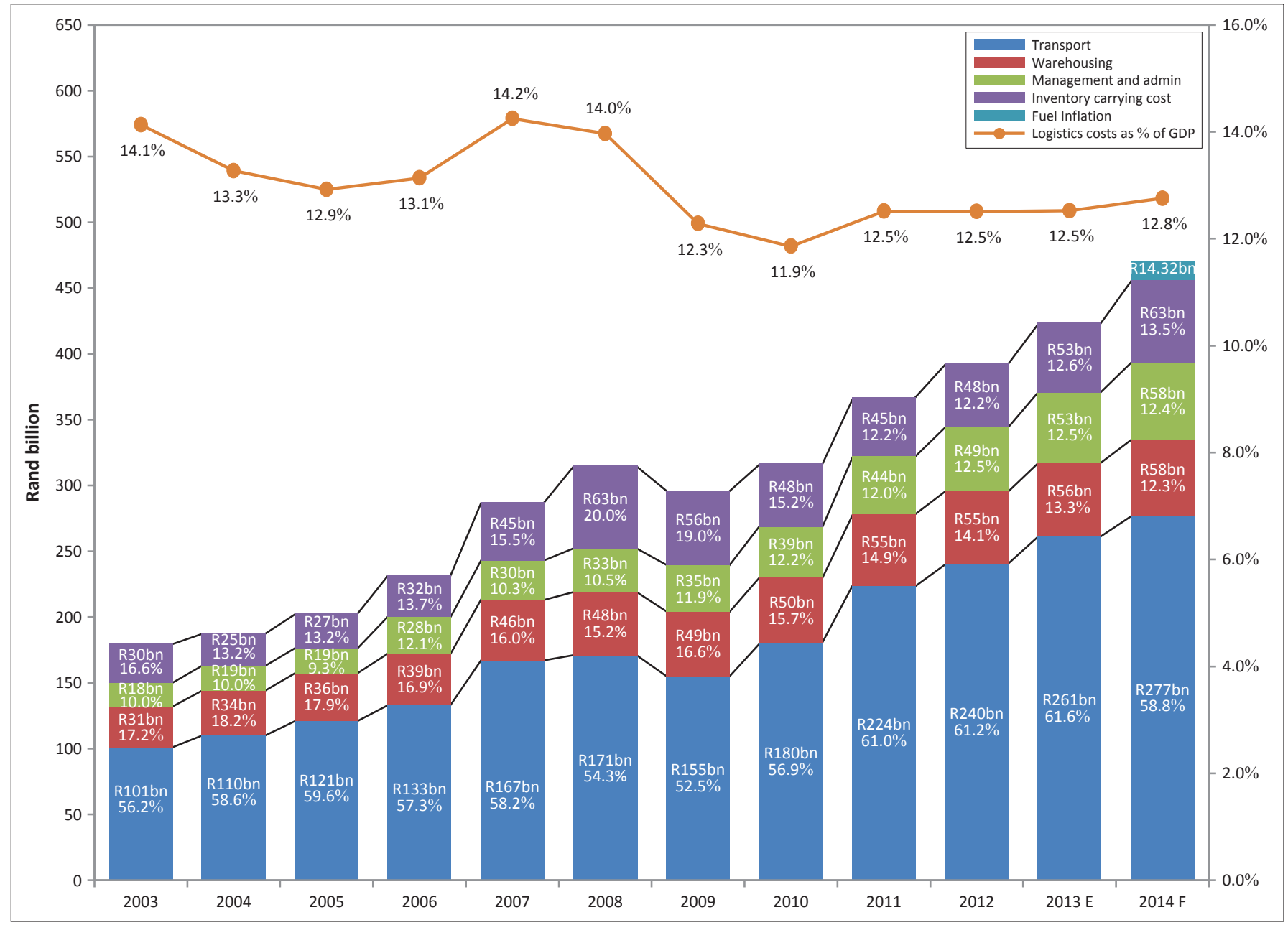

$E$, estimated; F, forecast; GDP, gross domestic product.

FIGURE 3: Total South African national logistics costs and the components, 2006-2014. 


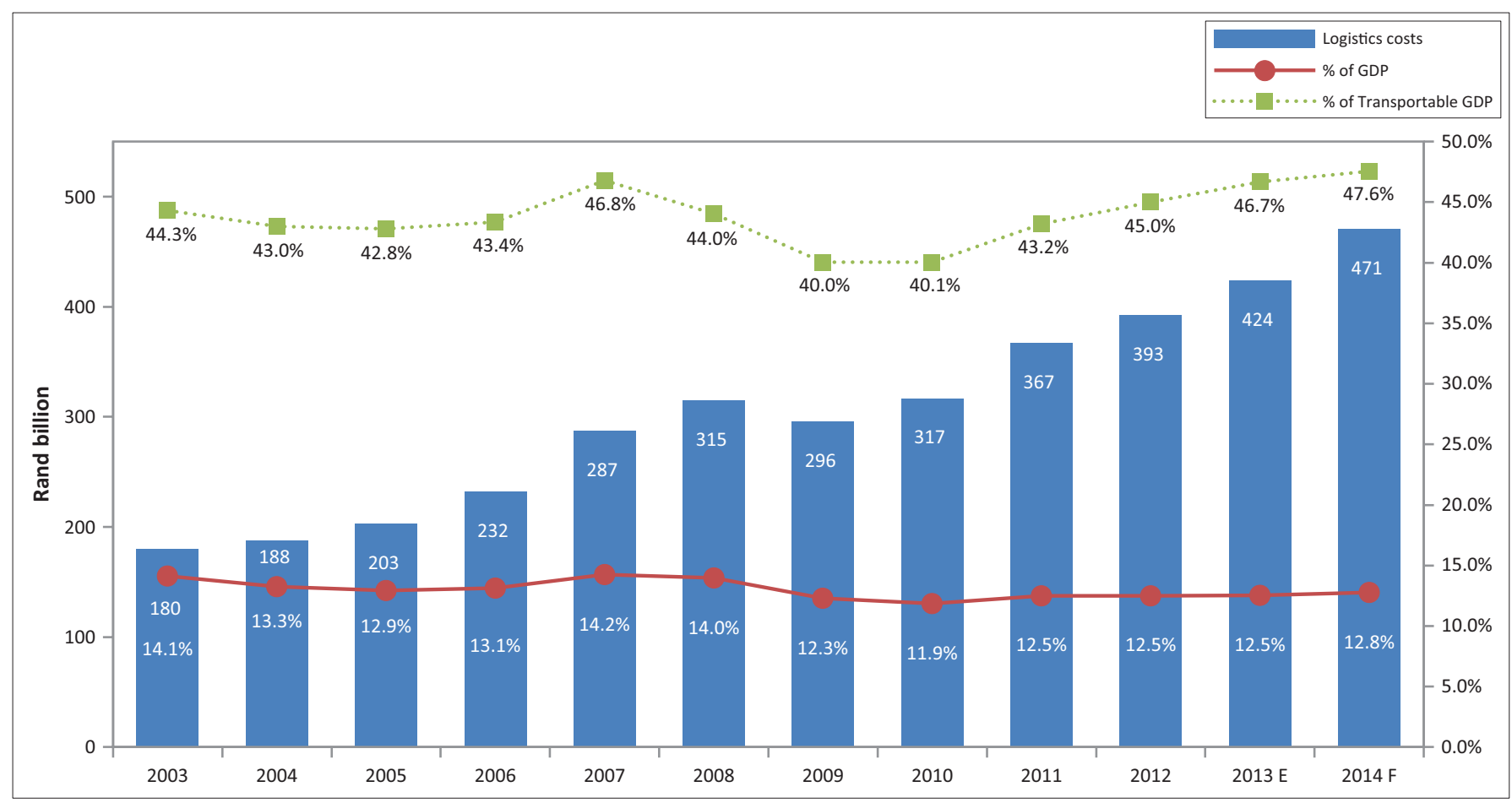

E, estimated; F, forecast; GDP, gross domestic product.

FIGURE 4: South African logistics costs as a percentage of total and transportable gross domestic product.

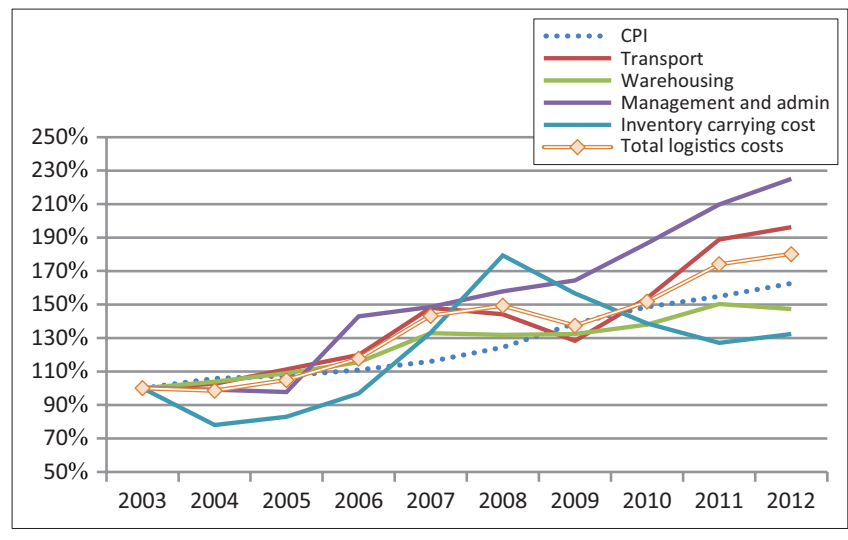

$\mathrm{CPI}$, Consumer Price Index.

FIGURE 5: Growth of South African logistics cost components compared to the Consumer Price Index, 2003-2012.

the conservative assumption of a $15 \%$ increase in the diesel price between 2013 and 2014, fuel inflation will be as big a component of logistics costs in 2014 as warehousing or management and administration (12\%).

South Africa is a net importer of oil and thus the price of fuel in the country depends heavily on the global crude oil price, as well as the Rand/Dollar exchange rate. An analysis of what the impact of these two variables on the national cost of logistics could have been in 2012 is shown in Table 1.

The fuel dependence resulted from the structure of South Africa's freight transport industry. South Africa is a transport intensive economy, requiring comparatively more tonne-kilometres to contribute $\$ 1.00$ to the GDP (Havenga et al. 2012). South Africa's heavy reliance on road transport is exacerbating this transport intensiveness. In 2012, 88.3\%

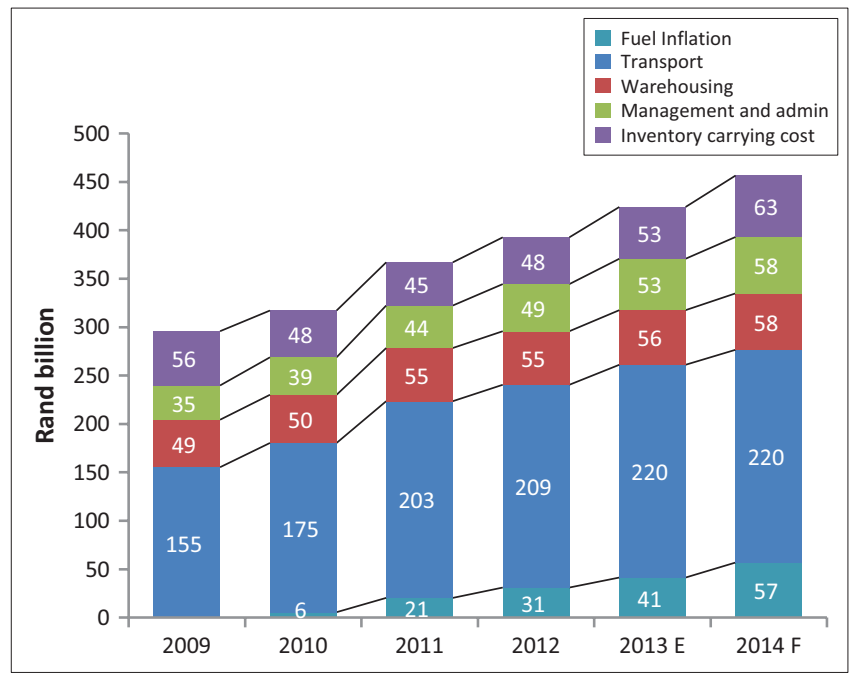

$E$, estimated; $F$, forecast.

FIGURE 6: The impact of fuel inflation on logistics costs since 2009.

of the country's freight tonnage was on road, accounting for $70.0 \%$ of the tonne-kilometres (estimated at $87.9 \%$ and $69.5 \%$ in 2013 for tonnage and tonne-kilometres respectively).

The reasons for this spatially challenged structure of the economy are threefold. Firstly, geographically, the discovery of gold and other minerals in the northern interior firmly established the hub of economic development away from the coastline and years of tertiary sector growth and urbanisation has now cemented Gauteng Province as the economic and demographic centre of the country - more than $600 \mathrm{~km}$ away from the nearest port. The sources of South Africa's primary bulk export commodities (coal, iron ore and manganese) are also far into the country's interior. Secondly, economically, South 
TABLE 1: The potential impact of the crude oil price and the exchange rate on national logistics costs in 2012.

\begin{tabular}{|c|c|c|c|c|c|c|}
\hline \multirow[t]{2}{*}{ Rand/Dollar exchange rate } & \multicolumn{2}{|c|}{ Crude oil price $\$ 100$} & \multicolumn{2}{|c|}{ Crude oil price $\$ 150$} & \multicolumn{2}{|c|}{ Crude oil price $\$ 300$} \\
\hline & $\begin{array}{l}\text { Change in total } \\
\text { logistics cost in } \\
\mathrm{R} \text { (billion) }\end{array}$ & $\begin{array}{l}\text { Logistics cost as } \\
\% \text { of GDP }\end{array}$ & $\begin{array}{l}\text { Change in total } \\
\text { logistics cost in } \\
\mathrm{R} \text { (billion) }\end{array}$ & $\begin{array}{l}\text { Logistics cost as } \\
\% \text { of GDP }\end{array}$ & $\begin{array}{l}\text { Change in total } \\
\text { logistics cost in } \\
\mathrm{R} \text { (billion) }\end{array}$ & $\begin{array}{l}\text { Logistics cost as } \\
\% \text { of GDP }\end{array}$ \\
\hline $\mathrm{R} 10.00 / \$ 1.00$ & 7.28 & 12.7 & 34.01 & 13.6 & 114.20 & 16.1 \\
\hline $\mathrm{R} 12.00 / \$ 1.00$ & 17.97 & 13.1 & 50.05 & 14.1 & 146.28 & 17.2 \\
\hline
\end{tabular}

GDP, gross domestic product.

Africa has followed the global route of economic specialisation; consequently, domestic distribution of agricultural and manufactured goods between dispersed economic centres is unduly transport intensive. South Africa's economic reliance on high-value imported consumer goods and low-value bulk exports exacerbates the situation. Lastly, segregated spatial planning policies upheld during the Apartheid era resulted in a demographic distribution that is transport-inefficient both, from a passenger and freight perspective.

McKinnon (2012) discusses various supply-side and demandside solutions to lowering transport intensity. Modal shift, better vehicle utilisation, improved fuel efficiency and cutting the carbon content of fuel are presented as supply-side solutions. Of these, the development of an effective and efficient domestic intermodal (rail-road) solution could potentially be a game-changer for South Africa. The merits and potential of a successful domestic intermodal solution is discussed by Havenga et al. (2012). Demand-side solutions are less researched but basically include a number of initiatives that shorten the logistics chain, for example reshoring, 3D printing and recycling at source (Havenga, Simpson \& De Bod 2013). The Global freight forwarding 2014 report produced by Transport Intelligence (2014) reports a decline in value of 3.3\% in the freight forwarding market during 2013, highlighting manufacturers' shift away from globalisation towards regionalisation as one of the key contributors to this decline.

\section{Discussion}

South Africa's absolute logistics costs and the logistics costs as a percentage of transportable GDP are rising. The macroeconomic viewpoint shared above, points to the stark reality that these trends most likely do not indicate increased logistics inefficiency, but rather the increase in underlying cost drivers, specifically the oil price. This cost driver cannot be controlled by government or industry and microeconomic efficiency gains are the only respite businesses may have. However, efficiency improvements may offer only marginal year-on-year savings as leanness improves. Similarly, there could still be scope for efficiency improvements in the road freight industry - especially pertaining to fuel efficiency - but these improvements will yield only marginal gains and will not curb the rising trend in logistics costs, given the structure of South Africa's freight transport market.

Possible improvements always point towards transport and logistics supply and demand. The three most important supply-side improvements are efficient trucks, more efficient logistics and modal shift. In Europe, where obvious gains from modal shift are less than in South Africa, recent studies, such as the work of Cebon (2014), show that logistics efficiency will yield much greater returns than efforts to try and make trucks even more fuel efficient. The case for modal shift has been clearly stated for South Africa, but further research is required on how to improve the efficiency of South Africa's logistics system on a meso and macro level.

Politico-economic measures, such as diversifying crude oil supply sources (Wabiri \& Amusa 2011) or reassessing the allocation of local fuel levies (CSIR 2014), could provide short-term relief. The most sustainable solution however, points to a significant reduction in the transport intensity of the South African economy.

\section{Conclusion}

This research illustrates the fact that certain risks therefore need to be mitigated from a macroeconomic point of view and points the way to a new and rising area of logistics research, that is 'macro-logistics'. Macro-logistics deals with national supply chains, infrastructure requirements and policy on a national planning level, as well as meso level collaboration between government and industry. It requires both analytical tools for mapping and quantification and performance management constructs.

\section{Acknowledgements Competing interests}

The authors declare that they have no financial or personal relationships that may have inappropriately influenced them in writing this article.

\section{Authors' contributions}

J.H.H. (Stellenbosch University) wrote and edited the article and undertook the research design, whilst Z.P.S. (Stellenbosch University) performed the analysis. A.D.B. (Stellenbosch University) was the responsible for project management and N.M.V. (Stellenbosch University) also helped with the writing of the article.

\section{References}

Arvis, J., Mustra, M.A., Panzer, J., Ojala, L. \& Naula, T., 2008, 'Connecting to compete: Trade logistics in the global economy', in R.Z. Lawrence, J. Blanke, M.D. Hanous \& J. Moavenzadeh (eds.), The global enabling trade report, pp. 1-3 , The World Economic Forum, Geneva.

Benes, J., Chauvet, M., Kamenik, O., Kumhof, M., Laxton, D., Mursula, S. et al., 2012, The future of oil: Geology versus technology, International Monetary Fund, Washington, DC.

Calderón, C. \& Servén, L., 2010, 'Infrastructure in Latin America', Policy Research Working Paper 5317, World Bank, Washington, DC. 
Cebon, D., 2014, 'Sustainable road freight transport: Developments in HGV technology', Paper presented at the Workshop on Sustainable Roadfreight, The Centre for Sustainable Road Freight, Cambridge, 02 September 2014.

Council for Scientific and Industrial Research (CSIR), 2014, 10th State of Logistics survey for South Africa 2013, CSIR, Pretoria.

Fedderke, J., Perkins, P. \& Luiz, J., 2006, 'Infrastructural investment in long-run economic growth: South Africa 1875-2001', World Development 34(6), 1037-1059. http://dx.doi.org/10.1016/j.worlddev.2005.11.004

Fields, B. \& Renne, J., 2013, Transport beyond oil: Policy choices for a multimoda future, e-book, eBook Collection (EBSCOhost), Ipswich.

Finger, M., 2013, ICC Open Markets Index: Second Edition 2013, viewed 21 November 2014, from http://www.iccwbo.org/global-influence/g20/reports-and-products/ open-markets-index/

Gilmore, D., 2013, State of the Logistics Union 2013, viewed 07 August 2014, from http://www.scdigest.com/assets/FIRSTTHOUGHTS/13-06-20.php?cid=7172

Grandes, M., Peter, M. \& Pinaud, N., 2003, The currency premium and local-currency denominated debt costs in South Africa, viewed 07 August 2014, from http:// www.oecd.org/dataoecd/52/44/23375078.pdf

Havenga, J.H., 2010, 'Logistics costs in South Africa - The case for macroeconomic measurement', South African Journal of Economics 78(4), 460-478. http://dx.doi. org/10.1111/j.1813-6982.2010.01252.x

Havenga, J.H. \& Simpson, Z.P., 2013, 'Logistics costs and efficiency', in 10th State of Logistics survey for South Africa 2013, pp. 2-19, CSIR, Pretoria.

Havenga, J.H. \& Simpson, Z.P., 2014, 'Reducing national freight logistics costs risk in a high-oil-price environment. A South African case study', The International Journal of Logistics Management 25(1), 35-53. http://dx.doi.org/10.1108/IJLM-11-2012-0133

Havenga, J.H., Simpson, Z.P. \& De Bod, A., 2012, 'South Africa's domestic intermodal imperative', Research in Transportation Business \& Management 5, 38-47. http:// dx.doi.org/10.1016/j.rtbm.2012.11.006

Havenga, J.H., Simpson, Z.P. \& De Bod, A., 2013, 'Macro-logistics trends: Indications for a more sustainable economy', Journal of Transport and Supply Chain Management 7(1), Art. \#108, 7 pages. http://dx.doi.org/10.4102/jtscm.v7i1.108

Hopkins, K., 2008, 'Fuel prices: Iran missile launches send oil to $\$ 147$ a barrel record', The Guardian, 12 July, viewed 07 August 2014, from http://www.guardian.co.uk/ business/2008/jul/12/oil.commodities

IndexMundi, 2014, Dated Brent Monthly Price, West Texas Intermediate Monthly Price, Dubai Fateh Monthly Price, viewed 21 November 2014, from http://www. indexmundi.com/commodities/?commodity=crude-oil-brent $\&$ months $=360$, http://www.indexmundi.com/commodities/?commodity=crude-oil-westtexas-intermediate\&months $=360$, http://www.indexmundi.com/commodities/? texas-intermediate $\&$ months $=360$, http: $/ /$
commodity=crude-oil-dubai\&months $=360$

Ittmann, H.W., 2012, 'Transport infrastructure and planning', in 9th State of Logistics survey for South Africa 2012, pp. 66-75, CSIR, Pretoria.

Kessides, C., 1993, The contributions of infrastructure to economic development: A review of experience and policy implications, World Bank, Washington, DC http://dx.doi.org/10.1596/0-8213-2628-7

Lakshmanan, T.R. \& Anderson, W.P., 2002, Freight services and economic growth A synopsis of a White Paper, The US Department of Transportation, Federal Highway Administration, Washington, DC

Limão, N. \& Venables, A.J., 2001, 'Infrastructure, geographical disadvantage, transport costs and trade', World Bank Economic Review 15(3), 451-479. http://elibrary.worldbank.org/doi/abs/10.1093/wber/15.3.451. http://dx.doi. org/10.1093/wber/15.3.451

Loayza, N. \& Odawara, R., 2010, 'Infrastructure and economic growth in Egypt', Policy Research Working Paper 5177, World Bank, Washington, DC
Macharis, C., Van Hoeck, E., Pekin, E. \& Van Lier, T., 2010, 'A decision analysis framework for intermodal transport: Comparing fuel price increases and the internalisation of external costs', Transportation Research Part A: Policy and internalisation of external costs, Transportation Research Part A: Policy and
Practice 44(7), 550-561. http://www.sciencedirect.com/science/article/pii/ Practice 44(7), 550-561. http://www.sciencedirect.com/scie
S0965856410000741. http://dx.doi.org/10.1016/j.tra.2010.04.006

McKinnon, A.C., 2012, 'Green logistics, global trends and issues', Presented at the World Bank Conference: Decoding Sustainable Logistics Trends, 12 June, World Bank, Washington, DC

Peak Oil, 2012, 'Crude oil is going to $\$ 500$ a barrel', viewed 15 November 2014, from http://peakoil.com/business/crude-oil-is-going-to-500-a-barrel

Radetzki, M., 2002, 'Is resource depletion a threat to human progress? Oil and other critical exhaustible materials', The Centre for Energy, Petroleum and Mineral Law and Policy - The Journal 10, viewed 07 August 2014, from http://www.dundee. ac.uk/cepmlp/gateway/index.php?news $=28178$

Rantasila, K. \& Ojala, L., 2012, Measurement of national-level logistics costs and performance: Discussion Paper 2012-04, International Transport Forum at the OECD, Paris.

Rasamit, T., 2003, 'The aggregate analysis of logistics costs and total factor productivity', MEng thesis, Department of Engineering, Massachusetts Institute of Technology.

Ravn, M.O. \& Mazzenga, E., 2004, 'International business cycles: The quantitative role of transportation costs', Journal of International Money and Finance 23(4), 645-671. http://dx.doi.org/10.1016/j.jimonfin.2004.03.001

Rodrigues, A.M., Bowersox, D.J. \& Calantone, R.J., 2005, 'Estimation of global and national logistics expenditures: 2002 data update', Journal of Business Logistics 26(2), 1-16. http://dx.doi.org/10.1002/j.2158-1592.2005.tb00202.x

South African Foreign Policy Initiative, 2013, South Africa's oil imports from Angola Ghana, Nigeria, viewed 07 August 2014, from http://www.safpi.org/news/ article/2013/south-africas-oil-imports-angola-ghana-nigeria

South African Reserve Bank, 2012, Series KBP5339J - Foreign exchange rate: SA cent per USA dollar middle rates, viewed 06 August 2014, from http://www.resbank. co.za/Research/Statistics/Pages/OnlineDownloadFacility.aspx

Tavasszy, L., Harmsen, J., Ivanova, A. \& Bulavskaya, T., 2014, Effect of a full internalization of external costs of global supply chains on production, trade and transport, Transport Research Arena, Paris, viewed 07 August 2014, from http:// www.traconference.eu/papers/pdfs/TRA2014_Fpaper_17858.pdf

Thicknesse, P.J., 2012, Strategic Trends Programme: Regional Survey - South Asia out to 2040, UK Ministry of Defence, London, viewed 15 November 2014, from https://www.gov.uk/government/uploads/system/uploads/attachment_data/ file/49954/20121129_dcdc_gst_regions_sasia.pdf

Transport Intelligence, 2014, Global freight forwarding 2014 - Regionalisation vs. globalization, viewed 06 August 2014, from http://www.transportintelligence. com/market-reports/report-global-freight-forwarding-2014/323/

Viljoen, N.M., 2013, 'Without fear or favour', Future Trucking \& Logistics 1(4), 22-23.

Wabiri, N. \& Amusa, H., 2011, 'South African crude oil import portfolio risks: Which way out?', Human Sciences Research Council - Policy brief, January 2011, viewed 07 August 2014, from http://www.hsrc.ac.za/uploads/ pageContent $/ 3328 / 2011$ febSouth $\% 20$ African $\% 20$ Crude $\% 200$ il $\% 20$ import $\% 20$ portfolio $\% 20$ risks.pdf

Wilson, R., 2011, 21st annual State of Logistics report: The great freight recession, Council of Supply Chain Management Professionals, Washington, DC.

World Bank, 2012, Crude oil average spot price (nominal \$/bbl), viewed 07 August 2014, from http://databank.worldbank.org/ddp/home.do?Step=12\&id=4\& CNO=1175

World Bank, 2013, Can infrastructure investments generate growth?, World Bank, Washington, DC. 